\title{
Z BADAŃ NAD STANEM INFORMATYZACJI POLSKIEGO SEKTORA MSP W WARUNKACH TRANSFORMACJI CYFROWEJ
}

\author{
PIOTR ADAMCZEWSKI ${ }^{1}$
}

Wyższa Szkoła Bankowa w Poznaniu

Instytut Zarządzania

${ }^{1}$ e-mail: adamczewski@wsb.poznan.pl

SŁOWA KLUCZOWE

STRESZCZENIE
ICT, MSP, SMAC, transformacja cyfrowa

Sektor MSP od lat należy do najdynamiczniej rozwijających się i informatyzujących obszarów polskiej gospodarki. Zaawansowane rozwiązania ICT (Information and Communication Technology) stanowią warunek sine qua non nowocześnie funkcjonujących przedsiębiorstw tego sektora i wpisują się w proces transformacji cyfrowej. W artykule omówiono aktualne tendencje rozwojowe w zakresie informatyzacji nowoczesnych przedsiębiorstw sektora MSP. Dokonano tego na bazie wyników badań własnych autora przeprowadzonych w okresie 2014-2016 w wybranych przedsiębiorstwach województw mazowieckiego i wielkopolskiego oraz odniesiono je do ogólnych tendencji rozwojowych w zakresie globalnej transformacji cyfrowej.

\section{Wprowadzenie}

Funkcjonowanie nowoczesnego przedsiębiorstwa wymaga dostosowania metod zarządzania i strategii rozwoju do warunków postępującej transformacji cyfrowej, która przejawia się w dokonywaniu zasadniczych zmian procesów organizacyjnych, produktów, usług i modeli biznesowych, wykorzystujących innowacyjne technologie cyfrowe i związane z nimi kompetencje personelu. Dynamiczny rozwój ICT wpływa nie tylko na sposoby działania i konkurowania po- 
jedynczych przedsiębiorstw (stosowane modele biznesowe, sposoby budowania relacji z klientami i partnerami biznesowymi czy też wykorzystywane formy organizacyjne), ale oddziałuje również znacząco na zmiany dokonujące się w całych sektorach gospodarki. Potencjał konkurencyjny MSP działających w Polsce jest duży (bardzo wysoka konkurencyjność cenowa, wysoka konkurencyjność pod względem jakości produktów i usług, poprawiająca się konkurencyjność pod względem innowacyjności), ale by mógł on być w pełni wykorzystywany, muszą zostać zniesione, albo przynajmniej ograniczone bariery, które przeszkadzają MSP w prowadzeniu działalności gospodarczej. Do jednych z nich należą bariery finansowe w zakresie inwestowania $\mathrm{w}$ infrastrukturę przedsiębiorstw, w tym również $\mathrm{w}$ infrastrukturę teleinformatyczną.

Celem artykułu jest ukazanie aktualnych tendencji rozwojowych w zakresie informatyzacji nowoczesnych przedsiębiorstw sektora MSP, ilustrowanych wynikami badań własnych autora przeprowadzonych w okresie 2014-2016 w wybranych przedsiębiorstwach województw mazowieckiego i wielkopolskiego wraz z odniesieniem ich do ogólnych tendencji rozwojowych w zakresie transformacji cyfrowej. Według badań Cisco Global Cloud Index w roku 2018 połowa populacji ludności świata będzie miała dostęp do internetu, a ponad 53\% tej populacji będzie korzystało z narzędzi do przechowywania danych w „,chmurze” (Cisco, 2014, s. 56).

\section{Modele rozwoju e-biznesu w selktorze MSP}

W literaturze przedmiotu prezentowane są dwa modele adaptacji e-biznesu w przedsiębiorstwach (Model biznesu, 2013, s. 259):

- model liniowy (,drabiny”),

- model warunkowy (,transportera”).

Model liniowy zakłada stopniowe, etapowe wdrażanie rozwiązań ICT przez przedsiębiorstwa. Sekwencja ta zgodna jest z generacjami e-biznesu, które można ująć w następujących etapach:

- dostęp do internetu (e-mail i przeglądarka internetowa),

- strona WWW przedsiębiorstwa,

- e-commerce (zakupy i sprzedaż przez internet),

- e-biznes (e-commerce wraz z systemami informatycznymi optymalizującymi działanie przedsiębiorstwa),

- tworzenie sieci z innymi przedsiębiorstwami (elektroniczne ekosystemy przedsiębiorstw) (Adamczewski, 2015, s. 76; Model biznesu, 2013, s. 262).

Model warunkowy opiera się na założeniu, że wdrażanie ICT w przedsiębiorstwach nie przebiega w sposób liniowy, lecz zależy od dwóch najważniejszych czynników:

- prognozowanego rozwoju przedsiębiorstwa,

- oczekiwanej użyteczności rozwiązań ICT.

Podstawowe założenie drugiego modelu oznacza, że adaptacja e-biznesu nie musi przebiegać liniowo. Określone rozwiązania, modele e-biznesu, mogą być adaptowane bez procedury sekwencyjnej po akceptacji kierownictwa organizacji. To ono decyduje o modyfikacji jej struk- 
tury, biorąc pod uwagę oczekiwane korzyści, gotowość i możliwości zmian w przedsiębiorstwie oraz czynniki zewnętrzne, takie jak presje organizacyjne i/lub technologiczne ze strony klientów lub kontrahentów.

E-przedsiębiorstwo jako układ ekonomiczny, wykorzystujący w swojej wewnętrznej organizacji i komunikacji - także zewnętrznej - zaawansowaną infrastrukturę teleinformatyczną, stanowi obecnie istotę funkcjonowania społeczeństwa informacyjnego w obszarach biznesowych. Oznacza to w praktyce wsparcie technologią informatyczną podstawowych struktur przedsiębiorstwa i realizacji koncepcji now economy (ekonomii chwili) w trybie online:

- poziom infrastruktury technicznej (sprzętowej),

- poziom infrastruktury systemowo-komunikacyjnej,

- poziom oprogramowania aplikacyjnego,

- poziom integracji procesów biznesowych kontrahentami zewnętrznymi przedsiębiorstwa.

Do promowania technologii ICT w przedsiębiorstwach MSP potrzebne są jednak m.in.:

- zaawansowane umiejętności techniczne i kierownicze (kultura informatyczna),

- udostępnienie MSP odpowiednich rozwiązań z zakresu e-biznesu,

- rozwiązanie barier kosztowych w zakresie zakupu sprzętu ICT,

- rozwiązanie kwestii bezpieczeństwa i prywatności,

- udostępnienie informacji na temat e-biznesu, które dotyczą samych MSP,

- promowanie e-administracji: obniżenie ogólnych kosztów administracji i stworzenie zachęt do prowadzenia e-biznesu.

Sektor MSP wiele zyskuje na swojej konkurencyjności, decydując się na stosowanie technologii informacyjnych i komunikacyjnych. Eliminuje to m.in. problem odległości, dzięki czemu przedsiębiorstwa mogą działać nie tylko lokalnie, ale i globalnie. A na dodatek nie wymaga to rozbudowywania kosztownych sieci biur i sklepów.

\section{Systemy SMAC}

Dynamiczny rozwój technologii teleinformatycznych ostatnich lat doprowadził do upowszechnienia się tzw. III platformy ICT, określanej również mianem SMAC (Social, Mobile, Analytics, (loud), a tworzącej swoisty ekosystem rozwiązań informatycznych, pozwalający organizacjom rozwijać swoją działalność przy mniejszych nakładach finansowych i maksymalnym zasięgu oddziaływania. Stale rosnące ilości danych, dostarczane przez urządzenia mobilne, platformy społecznościowe, przeglądarki internetowe i programy lojalnościowe, tworzą nowy model biznesu oparty na informacjach generowanych przez środowisko gospodarcze. Odpowiednie przetworzenie tych informacji jest warunkiem koniecznym do osiągnięcia biznesowego sukcesu.

Nowoczesne przedsiębiorstwo sektora MSP oznacza w praktyce wsparcie technologią ICT w trybie online poziomu:

- infrastruktury technicznej (sprzętowej), 
- infrastruktury systemowo-komunikacyjnej,

- oprogramowania aplikacyjnego,

- integracji procesów biznesowych z kontrahentami zewnętrznymi (Adamczewski, 2016, s. 420; Model biznesu, 2013, s. 44).

Dynamiczny rozwój ICT doprowadził do wykształcenia się nowego standardu technologicznego, jakim są systemy SMAC, umożliwiające realizowanie nowych modeli biznesowych. Opierają się na czterech filarach:

I. Social - sieci społecznościowe przełamują bariery przepływu informacji między ludźmi i stają się platformami, dzięki którym szybka wymiana wiedzy jest coraz bardziej efektywna. Komunikacja w ramach platform społecznościowych bardzo mocno wypiera komunikację telefoniczną czy mailową. Zjawisko to ma miejsce również w obszarze biznesowym, gdzie szybka wymiana informacji jest niezwykle ważna. Wykorzystanie sieci społecznościowych pozwala na uzyskanie lepszej interakcji z klientami, dzięki czemu możliwe staje się szybsze reagowanie na problemy i budowanie bazy wiedzy na podstawie preferencji i zachowań użytkowników. Pracownicy zrzeszeni w społeczność mogą dużo łatwiej i szybciej wymieniać doświadczenia, interesujące treści i przyspieszać rozwiązywanie problemów.

II. Mobile - urządzenia mobilne, takie jak smartfony i tablety, na stałe zagościły już w naszym życiu. Zwiększyły również możliwość dotarcia firm do klientów, którzy korzystając z urządzeń mobilnych, przyzwyczaili się do robienia zakupów i używania różnego rodzaju serwisów i aplikacji w każdym czasie i w każdym miejscu. Wzrost popularności zakupów mobilnych jednocześnie wymógł na przedsiębiorcach konieczność rozwijania swoich kanałów marketingu internetowego oraz udostępniania klientom kanałów mobilnych. W tych warunkach prezentowanie oferty na urządzeniach mobilnych jest podstawą do zdobycia lub utrzymania wysokiej pozycji rynkowej.

III. Analytics - zrozumienie zachowań i preferencji klientów jest jedną z największych zalet korzystania z narządzi analitycznych. Z zebranych danych, analizowanych przez zaawansowane algorytmy, przedsiębiorcy są w stanie wywnioskować, jak zadbać o lojalność klientów, ulepszyć kampanie marketingowe, usprawnić procesy rozwoju produktów i świadczyć usługi, które pasują do preferencji i wymagań klientów. Dzięki poznaniu upodobań użytkowników przedsiębiorcy są w stanie m.in. prezentować treści zgodne z ich oczekiwaniami. Nadrzędnym celem wykorzystania narzędzi analitycznych w prowadzeniu biznesu jest zatem podejmowanie prawidłowych decyzji na podstawie aktualnych i zagregowanych informacji.

IV. Cloud - technologia chmury obliczeniowej oferuje narzędzia umożliwiające sprawne gromadzenie informacji i skuteczne zarządzanie przedsiębiorstwem. Korzystanie z narzędzi dostępnych w chmurze pozwala organizacjom na obniżenie kosztów ICT, przełamanie barier geograficznych i posiadanie dostępu do danych w dowolnym czasie i miejscu. Chmura jest czynnikiem, który spaja pozostałe elementy składające się na SMAC.

Na przestrzeni lat nie brakuje licznych przykładów, które świadczą o rozmijaniu się oczekiwań i faktycznych korzyści w zakresie wykorzystywania rozwiązań ICT. Przyczyną takiego efektu może być brak odpowiedniego stopnia integracji pomiędzy wdrażanymi systemami. 
Kluczem do odniesienia sukcesu przy zastosowaniu technologii SMAC jest połączenie czterech wspomnianych technologii, które komunikując się między sobą, pozwalają na uzyskanie efektu synergii. Żadna z tych czterech technologii nie daje pełnego efektu samodzielnie. Jedynie synergia wytworzona przez wszystkie elementy SMAC pracujące wspólnie pozwala na stworzenie przewagi konkurencyjnej. Organizacje inwestowały do tej pory w mobilność, chmurę, analitykę biznesową oraz wykorzystanie w biznesie mediów społecznościowych, tworząc samodzielne, najczęściej niewspółpracujące rozwiązania. Połączenie ich w ramach trzeciej platformy ICT umożliwia tworzenie nowych usług generujących przychody, pogłębiających relację z klientami, a także poprawiających efektywność funkcjonowania organizacji (Raport Bezpieczeństwo informacji, 2014, s. 198).

Dzięki rozwojowi systemów SMAC udało się przejść od zamkniętych systemów komunikacji do platform społecznościowych (Barry, 2013, s. 45). Głęboko i trwale zmieniło to system pracy i komunikację biznesową. Kanały społecznościowe umożliwiły szybkie tworzenie i udostępnianie treści, szerszą dystrybucję informacji, a także lepszą współpracę i interakcję z klientami. Technologie mobilne pozwoliły na uzyskanie łatwego dostępu do informacji poprzez nieustanne połączenie z internetem. Analizy danych są wykorzystywane w celu optymalizacji zarządzania relacjami z klientami oraz zwiększania efektywności kanałów sprzedaży. Chmura jest natomiast w wielu przedsiębiorstwach podstawą systemów ICT, zwiększającą ich elastyczność, skalowalność i wpływającą na redukcję kosztów przetwarzania danych. Organizacje chcące utrzymać swoją pozycję na konkurencyjnym rynku muszą być gotowe na dostarczenie klientom usług w pełni dostosowanych do ich potrzeb. Dzięki rozwojowi SMAC technologie informatyczne nie są już tylko wsparciem w rozwijaniu biznesu, ale punktem zwrotnym, który daje przewagę organizacjom i pozwala im wyróżnić się na tle konkurencji. SMAC dostarcza odpowiednie informacje w odpowiednim czasie, co umożliwia podejmowanie właściwych decyzji i efektywną współpracę zarówno wewnątrz, jak i na zewnątrz organizacji, czyli w całych łańcuchach kooperacji.

Swoisty ekosystem informatyczny e-przedsiebiorstwa opiera się zazwyczaj na zaawansowanych rozwiązaniach klasy ERP (Enterprise Resource Planning). Tradycyjnie rozumiane systemy ERP jako rozwiązania integrujące infrastrukturę informacyjną organizacji już nie wystarczają. Ich podstawowa funkcjonalność została wzbogacona o systemy zarządzania kontaktami z klientami (CRM - Customer Relationship Management), systemy zarządzania kontaktami $\mathrm{z}$ dostawcami (SRM - Supplier Relationship Management), systemy zarządzania łańcuchem dostaw (SCM - Supply Chain Management) i systemy zarządzania cyklem życia produktu (PLM - Produkt Lifecycle Management). Systemy SMAC poprzez swoje właściwości pozwalają na podniesienie efektywności obsługi informacyjnej procesów biznesowych, a w rezultacie końcowym - na wyższą konkurencyjność rynkową. Można nawet zaryzykować stwierdzenie, że rozwiązania te przestały już być dla organizacji sposobem na zdobycie przewagi konkurencyjnej, a stały się aktualnie wręcz czynnikiem decydującym o utrzymaniu się na rynku globalnym. 


\section{Stan informatyzacji polskiego sektora MSP}

Postępująca transformacja cyfrowa oznacza dla przedsiębiorstw jakościowy rozwój i przejawia się w dokonywaniu zasadniczych zmian procesów organizacyjnych, produktów, usług, modeli i ekosystemów biznesowych przy użyciu innowacyjnych technologii cyfrowych i związanych z nimi kompetencjami. Według badań autora przeprowadzonych w latach 2014-2016 na wybranej próbie stu przedsiębiorstw sektora MSP w województwach mazowieckim i wielkopolskim stopień upowszechnienia się informatycznego wspomagania procesów zarządzania w poszczególnych obszarach MSP można ująć następująco (procent badanych przedsiębiorstw):

- obszar finansowo-księgowy - 82\%,

- zasoby ludzkie - 71\%,

- gospodarka magazynowa - 58\%,

- zarządzanie produkcją - 19\%,

- zarządzanie relacjami z klientami - 49\%,

- wspomaganie prac biurowych - 93\% (tym 98\% obsługi poczty elektronicznej),

- obsługa procesów zakupowych lub sprzedażowych - 54\%,

- dla 25\% badanych najważniejszym trendem w informatyzacji jest dynamiczny rozwój systemów informatycznych wspierających ich rozwój,

- 23\% badanych przedsiębiorstw największe znaczenie przypisuje rozwojowi internetowych narzędzi handlowych (np. sklepom internetowym czy zamawianiu usług przez internet) (Adamczewski, 2015, s. 33).

Badane przedsiębiorstwa powszechnie używają laptopów i komputerów stacjonarnych (98\% wskazań). Średnio posiadają około 13 komputerów. Zdecydowana większość korzysta również z telefonów stacjonarnych i komórkowych/smartfonów. Tablety używane są natomiast w co trzecim przedsiębiorstwie (36\%). W tym przypadku średnio na firmę przypadają cztery tablety. Dopełnieniem powyższych statystyk jest wskaźnik 45\% w zakresie wykorzystywania w swoim działania komunikatorów internetowych oraz wspomagania się ,zewnętrznymi” siłami ICT (freelancer) na poziomie 55\%. Najczęściej firmy nie stosują wielowarstwowych zabezpieczeń przetwarzania danych - wybierają tylko podstawowe programy antywirusowe ( $88 \%$ wskazań). Co drugie przedsiębiorstwo (53\%) zabezpiecza swoje dane poprzez odgórnie ujednoliconą politykę haseł ustalanych i zarządzanych przez kierownictwo. Z kolei niecała połowa badanych (46\%) szyfruje pocztę e-mail.

Jedynie co trzecia firma korzysta z backupu danych (35\%). W tej liczbie aż $88 \%$ ma ten proces zautomatyzowany. Co ciekawe, backup jako środek zabezpieczający firmowe dane częściej stosują podmioty, które nie uważają bezpieczeństwa ICT za obszar kluczowy dla swojej działalności.

W zakresie wykorzystywania rozwiązań SMAC statystyki krajowe oddają ogólne tendencje światowe w tym zakresie, tj.:

- chmura - wykorzystywana jest w 18\% przedsiębiorstw (plan jej uruchomienia ma 38\% badanej populacji), 
- mobilność - wykorzystywana jest w 29\% przedsiębiorstw (plan jej uruchomienia ma $15 \%$ badanej populacji),

- analityka - wykorzystywana jest w 9\% przedsiębiorstw (plan jej uruchomienia ma $16 \%$ badanej populacji),

- media społecznościowe deklaruję już 45\% polskich przedsiębiorstw, a najbliższe plany ich wykorzystania prognozowane są na poziomie 55\% (Report IDC, 2016, s. 39).

Dopełnieniem trendów rozwojowych polskiego sektora MSP w transformacji cyfrowej są deklarowane inicjatywy innowacyjne w zakresie doskonalenia metod zarządzania organizacjami:

- cyfryzacja biura $-70 \%$,

- modernizacja infrastruktury teleinformatycznej - $64 \%$,

- konsolidacja w zakresie informacji i zaawansowanej analityki - 49\%,

- nowe aplikacje mobilne dla personelu - 49\%,

- praca grupowa $-49 \%$,

- mobilne aplikacje samoobsługowe dla klientów - 30\% (por. Report IDC, 2016, s. 77).

Według prognoz IDC w najbliższych dwóch latach $80 \%$ firm globalnych zainicjuje projekty transformacji cyfrowej w zakresie zarządzania wiedzą, opierając to na systemach SMAC, z czego aż 50\% nakładów będzie związanych z rozwiązaniami III platformy ICT (Report IDC, 2016, s. 37).

Polskie nowoczesne przedsiębiorstwa sektora MSP coraz śmielej sięgają po zaawansowane rozwiązania z zakresu systemów SMAC. Rosnące wymagania przedsiębiorstw w zakresie informatycznego wspomagania zarządzania wiedzą wynikają generalnie $\mathrm{z}$ ich funkcjonowania w czasie rzeczywistym (RTE - Real Time Enterprise). Z tego tez względu systemy SMAC pozwalają podnieść efektywność gospodarowania na wyższy poziom poprzez:

- skuteczniejsze docieranie do klientów - wykorzystując rozwiązania mobilne,

- lepsze zrozumienie potrzeb klientów - wykorzystując wysoko przetworzone systemy analityczne,

- skuteczniejsze komunikowanie z klientami - wykorzystując media społecznościowe,

- obniżając koszty przetwarzania danych - wykorzystując rozwiązania chmurowe.

Rozwiązania III platformy ICT wespół z technologiami Internetu Rzeczy (Internet of Things) przyczyniają się do jakościowego rozwoju funkcjonowania polskiej gospodarki. Wykorzystywanie zaawansowanych systemów w tym zakresie staje się nie tylko wymogiem skutecznego konkurowania organizacji na rynkach globalnych, ale wręcz wyzwaniem równania do najlepszych firm światowych.

\section{Kieprunki rozwoju e-biznesu w sektorze MSP}

Rosnące wymagania pod adresem systemów nowoczesnej infrastruktury teleinformatycznej MSP wynikają generalnie z funkcjonowania przedsiębiorstwa czasu rzeczywistego (RTE - Real Time Enterprise), co najpełniej realizowane jest na gruncie rozwiązań e-biznesu. Główne 
tendencje rozwojowe, jakie już wyraźnie rysują się na gruncie tej klasy rozwiązań, można ująć następująco:

- coraz szerszy zakres usług biznesowych,

- pełne informatyczne wspomaganie struktur wirtualnych,

- upowszechnianie się technologii internetowych (w tym portali korporacyjnych, usług sieciowych i przeglądarek WWW jako podstawowego interfejsu do systemów ERP),

- pełniejsze wykorzystywanie rozwiązań mobilnych, które umożliwią uprawnionym użytkownikom dostęp do zasobów informacyjnych organizacji poprzez dowolne medium,

- przechodzenie na architekturę komponentową,

- pogłębiająca się integracja funkcjonalna i technologiczna rozwiązań ICT,

- automatyczne konfigurowanie systemu przy dużej jego parametryzacji, co wpływa na skrócenie procesu jego wdrażania,

- szersze stosowanie hurtowni danych i zaawansowanej analityki, niezbędnych do szybkiego pozyskiwania informacji zarządczych i systemów zarządzania wiedzą,

- pełna otwartość na inne rozwiązania segmentowe poprzez integrację z systemami CAD/ CAM, automatyki przemysłowej, GIS, GPS, IoT itp.,

- pełniejszy outsourcing informatyczny, w tym głównie model SaaS i centra danych,

- wykorzystywanie aplikacji opartych na modelu „chmury” staje się normą, a to głównie za sprawą standaryzacji przeglądarek i działających w nich aplikacji, miniaturyzacji i standaryzacji urządzeń końcowych oraz postępującej rewolucji mobilnej w ramach III platformy ICT.

Ponieważ internet zmusza przedsiębiorstwa do budowania pogłębionych relacji z klientami, dostawcami i partnerami, systemy SMAC stają się atrakcyjną strategią zarówno z punktu widzenia samego biznesu, jak i wyboru stosowanego oprogramowania aplikacyjnego. Oznacza to konieczność stopniowej migracji eksploatowanych systemów przetwarzania danych w kierunku zintegrowanego środowiska rozwiązań SMAC, a tym samym - wzrostu zdolności adaptacyjnych przedsiębiorstw je eksploatujących. Jednocześnie funkcjonalność tych rozwiązań rozbudowywana jest o nowości technologiczne, których tendencje rozwojowe określane są przez:

- łatwość korzystania z tych narzędzi przez użytkowników, którzy nie są informatykami z wykształcenia,

- zgodność rozwiązań ze strategią funkcjonowania organizacji ilustrujące określone wskaźniki w postaci tzw. kokpitów menedżerskich,

- zaufanie do źródeł pochodzenia danych i ich strumieni (metadanych) w ramach całego łańcucha informacyjnego,

- innowacyjność rozumianą jako zdolność znajdowania nowych obszarów zastosowań w zakresie wspomagania decyzji biznesowych.

Na rozwój informacyjnej infrastruktury e-przedsiębiorstw największy wpływ mają ewoluujące potrzeby biznesowe oraz rozwój technologii informatycznej. Na kształcie tych rozwiązań waży także aktualna koniunktura gospodarcza, ostra konkurencja między dostawcami tych rozwiązań oraz wzrastająca wśród kadry zarządzającej kultura organizacyjno-informatyczna. 
Jest ona tym większa, im bardziej zaawansowane systemy klasy ERP integrowane są z rozwiązaniami inteligencji biznesowej. W prostej linii przekłada się to na efektywniejsze procesy informacyjno-decyzyjne, które stanowią podstawę koncepcji now economy, co na gruncie nowocześnie funkcjonujących przedsiębiorstw przejawia się zdobywaniem i umacnianiem przewagi konkurencyjnej.

Obserwacja ostatnich lat w zakresie rozwoju polskiego e-biznesu w sektorze MSP pozwala wyprowadzić następujące uogólnienia:

- jakość infrastruktury ICT oraz rozwiązań aplikacyjnych znacząco się poprawiła na przestrzeni ostatnich lat,

- w bardziej zaawansowanych rozwiązaniach przedsiębiorstwa stosują systemy ewoluujące od obsługi transakcji do świadczenia usług, co w efekcie pozwala na stworzenie bardziej zrównoważonych relacji z klientami,

- niezależnie od trendu koncentrującego się na obsłudze klientów, ważnym aspektem stosowania ICT jest zwiększanie wydajności procesów wewnętrznych, a to poprawia procesy planowania i podejmowania decyzji,

- konsekwencją stosowania bardziej zaawansowanych rozwiązań e-biznesu jest wykorzystywanie outsourcingu określonych procesów biznesowych, np. zaopatrzenia czy sprzedaży,

- wyraźnie rośnie zainteresowanie rozwiązaniami SMAC (Adamczewski, 2016, s. 36; Kisielnicki, 2013, s. 266; Modele biznesu, 2013, s. 67; Raport Czas na przyspieszenie, 2016, s. 127) .

\section{Podsumowanie}

Przemiany gospodarcze i ewolucja relacji biznesowych powodują w sektorze MSP dewaluację tradycyjnych źródeł przewagi konkurencyjnej, takich jak kapitał, infrastruktura, dostęp do rynków zbytu czy jakość oferowanych produktów i usług. E-przedsiębiorstwa, chcąc skutecznie konkurować na rynku, muszą nadać decydujące znaczenie elastyczności organizacji i jej zdolności do wdrażania innowacyjnych modeli biznesowych oraz reorganizacji procesów. Przykłady wielu polskich przedsiębiorstw MSP wskazują, że wizja nowocześnie zarządzanego biznesu weszła w dynamiczną fazę realizacji, a do rangi paradygmatu urasta docelowo efektywne zarządzanie wiedzą w e-przedsiębiorstwie z wykorzystaniem zaawansowanych rozwiązań ICT. Poza wszelką wątpliwością pozostają kwestie wydobywania rezerw, tkwiących jeszcze w sektorze MSP, poprzez wspomaganie jego funkcjonowania zaawansowanymi systemami teleinformatycznymi, w których poczesne miejsce zajmują rozwiązania z wykorzystaniem rozwiązań SMAC. 


\section{Litepaturg}

Adamczewski, P. (2016). Organizacje inteligentne wobec wyzwań e-gospodarki. W: Ekonomiczne problemy usług, 123. Szczecin: Wydawnictwo Naukowe Uniwersytetu Szczecińskiego.

Adamczewski, P. (2015). Polish SMEs as Intelligent Organizations - Conditions of the ICT Support. W: IT for Practice 2015. Ostrava: Technical University Ostrava.

Barry, D.K. (2013). Web Services. Service-Oriented Architectures and Cloud Computing. New York: Morgan Kaufmann Publishers.

Cisco Global Cloud Index 2013-2018 (2014). Cisco Systems Inc. San Jose.

Kisielnicki, J. (2013). Systemy informatyczne zarzadzania. Warszawa: Placet.

Duczkowska-Piasecka, M. (red.). (2013). Model biznesu. Nowe myślenie strategiczne. Warszawa: Difin.

Raport Bezpieczeństwo informacji - bezpieczna przyszłość (2014). Na podstawie The Global State of Information Security. Warszawa: Pricewaterhouse Coopers.

Raport Czas na przyspieszenie. Cyfryzacja Gospodarki Polski (2016). Polityka Insight na zlecenie ThinkTankCyfrowy. $\mathrm{pl}(15.07 .2016)$.

Report IDC FutureScape “Worldwide IT Industry” (2016). Leading Digital Transformation to Scale. New York.

\section{RESEARCH ON THE STATE OF ICT SUPPORT IN SME'S IN CONDITIONS OF DIGITAL TRANSFORMATION}

\section{KEYWORDS | digital transformation, ICT, SMAC, SME}

ABSTRACT $\quad$ An active sector of small and medium enterprises (SME) in Poland is a prerequisite of a properly functioning market economy. This sector encompasses various companies. The ICT (Information and Communication Technology) can help even the odds. SMAC (social, mobile, analytics and cloud) is the concept that four technologies are currently driving business innovation. SMAC creates an ecosystem that allows a business to improve its operations and get closer to the customer with minimal overhead and maximum reach. We have conducted a questionnaire-based survey to identify how polish SMEs perceive this phenomenon of e-business systems in era of digital transformation. 